\title{
Professional knowledge of tennis coaches
}

\author{
Caio Cortela (BRA), Michel Milistetd (BRA), Larissa Galatti (BRA), Miguel Crespo (ESP), \\ and Carlos Balbinotti (BRA)
}

ITF Coaching and Sport Science Review 2016; 70 (24): 10 - 12

\begin{abstract}
The role played by the coach, an emerging profession in terms of importance, is key to the growth of sport regardless of the sport in question. This study presents the most valued professional insights for tennis coaches, in order to contribute to current research, which can assist the institutions responsible for training coaches in promoting meaningful activities, which are close to the interests of the learner.
\end{abstract}

Key words: Interpersonal knowledge, professional knowledge, intrapersonal knowledge

Received: 20 March 2016

Accepted: 30 June 2016

Corresponding author:

Caio Cortela

Email: capacitacao@fpt.com.br

\section{INTRODUCTION}

To be a coach and work with excellence in different environments, one needs to master different skills and a range of expertise in different areas. According to the International Council for Coaching Excellence (ICCE, 2012) the ability to work effectively in a complex and dynamic environment such as the sports coaching industry, requires a solid knowledge base (professional, interpersonal and intrapersonal) that supports various skills such as vision, organization, leadership, communication, personal relationships, evaluation, reflection, in addition to a series of values that guide professional practice. Recent literature by Côté and Gilbert (2009) and Gilbert and Côté (2013) presented a conceptual definition of the different knowledge that forms the basis of the practice of sports coaching. Although this definition subdivides the types of knowledge, the authors reiterated that knowledge is interrelated, and by thinking of this in an isolated way can minimize the importance of reflective and complex interactional nature of sports coaching.

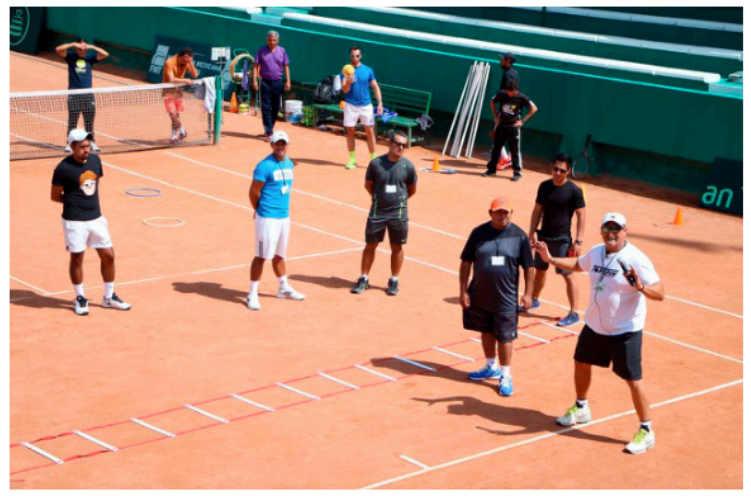

In this perspective, it is understood as professional knowledge, scientific and technical fields that form the basis of the performance of athletic coaches (Côté, Gilbert, 2009). Interpersonal knowledge is related to aspects of the relationship of the coach with their athlete and the coach's ability to communicate and relate effectively in this environment (Gilbert, Côté, 2013). Intrapersonal knowledge refers to the ability to self understand, ethical insights and reflections made by the coach (Côté, Gilbert, 2009). For an understanding of this conceptual idea applied to tennis coaches,
Figure 1 presents specific aspects that involve the area:

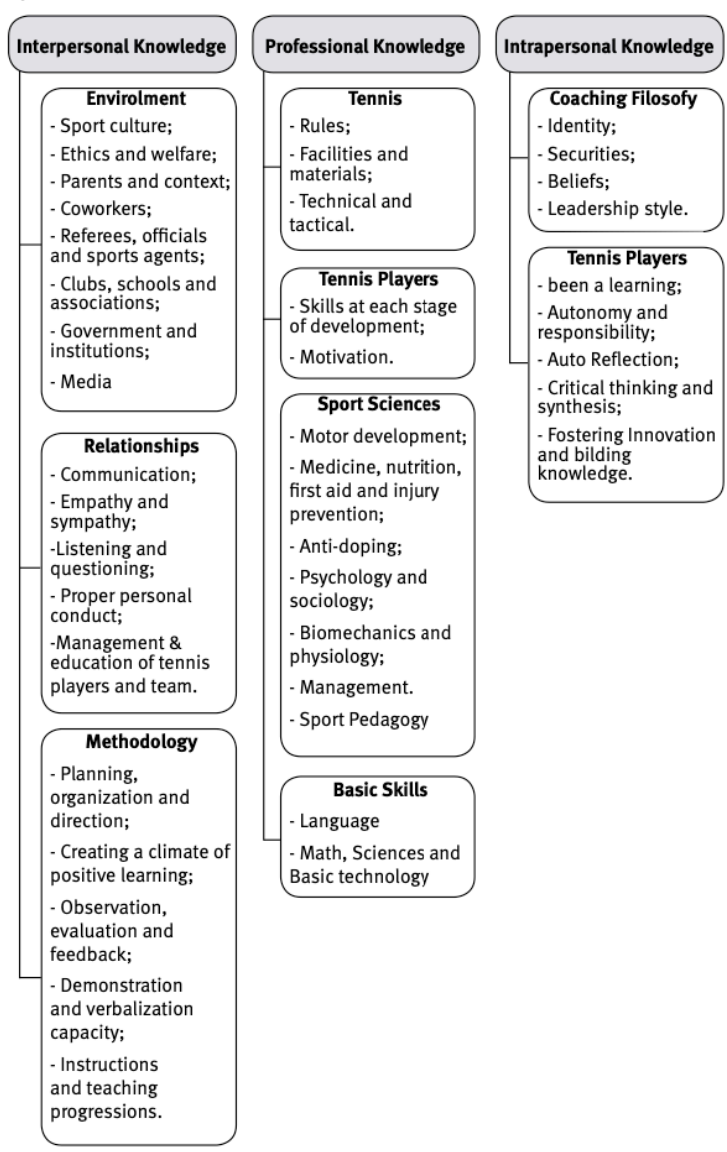

Figure 1 - Knowledge needed for tennis coaches (Adapted from Côté and Gilbert, 2009, Gilbert and Côté, 2013).

Traditionally, the coaches' training programs is based on their Professional Knowledge structures (Côté, Gilbert, 2009). To be considered as the experts of sports coaching, the coaches themselves seem to value these contents, because they related to specific fields and are applied from the sports in which they work (Cortela et al., Fuentes, Villar, Resende, Mosque, Romero, 2007). Based on this understanding, the purpose of the study was to describe the perception of tennis coaches on the 
Professional Knowledge, and the importance attached to the contents belonging to each category of this knowledge.

\section{METHODS}

Samples

73 tennis coaches (32.9 \pm 9.6 years) participated in this study having signed an informed consent form, from the state of Paraná, southern Brazil. The sample was composed mostly of male professional players (93.2\%), $57.5 \%$ of them with more than five years of professional experience, and $56 \%$ with academic qualifications at a higher level (22\% in Physical Education and $34 \%$ in other areas). Coaches reported to have participated frequently $(79.2 \%)$ on the training courses offered by the Brazilian Tennis Confederation. Approximately $66 \%$ of the coaches who participated in these courses were present on four or more courses in the last five years. Regarding the experience as a player, $57 \%$ were classified as first or second class in the Paranaense Tennis Federation, on a scale of eight, where the first is the highest level and the eighth lowest.

Instruments

The instruments used for data collection were: a sociodemographic questionnaire, and the Scale of Auto Competence Perception (EAPC) of sports coaches, validated to the Brazilian reality by Egerland (2009). The Professional Knowledge dimension of scale consists of 46 items, belonging to four categories: Management and Sports Law; Biodynamic; Psycho-socio-cultural aspects of sport; and Theory and Methodology of Training. Through a Likert five-point type scale, coaches inform the degree of dominance $(1=$ not dominate and $5=$ mastered $)$, and the importance given ( $1=$ not important and $5=$ great importance), to the knowledge.

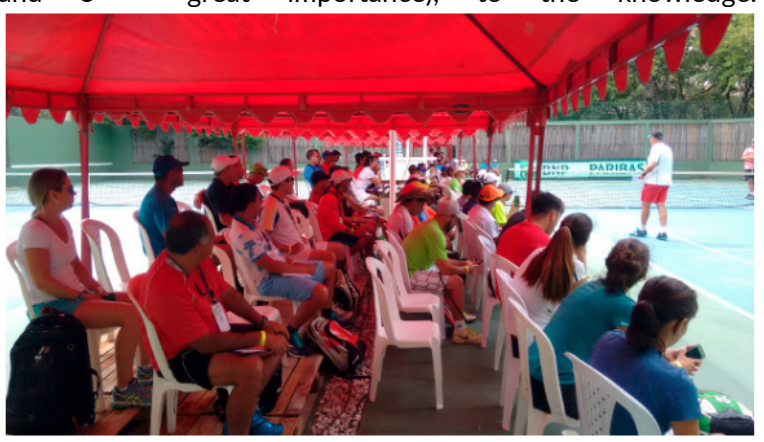

Procedures for collecting and analyzing data

Data collection occurred in person at the Tennis Manager Paranaense Meeting, held in August 2015 in three distinct regions of the state. Statistical analysis was performed using Microsoft Excel 2010 software. Frequency calculations and descriptive statistics were analysed.

\section{RESULTS AND DISCUSSION}

From the data in Table 1, it can be seen that the participants generally reported to dominate reasonably or well in the Professional Knowledge-related content. The knowledge related to the Theory and Methodology of training, at the psycho-socio-cultural aspects, and the Biodynamic of Sports, respectively in that order, presented the highest results by the coaches.

\begin{tabular}{|c|c|c|c|c|}
\hline \multirow{2}{*}{ Professional Knowledge } & \multicolumn{2}{|c|}{$\begin{array}{c}\text { Competence } \\
\text { perceived }\end{array}$} & \multicolumn{2}{|c|}{$\begin{array}{c}\text { Importance } \\
\text { attached }\end{array}$} \\
\hline & Mean & SD & Mean & SD \\
\hline \multicolumn{5}{|l|}{ Management and Sports Law Knowledge } \\
\hline Management and organization & 3,23 & 0,80 & 3,92 & 0,95 \\
\hline Basic legislation & 2,88 & 1,01 & 3.58 & 0,99 \\
\hline Legislation and doping & 2,45 & 1,02 & 3,69 & 0,99 \\
\hline Official functions & 3,04 & 1,11 & 3,79 & 0,93 \\
\hline TOTAL & 2,09 & 0,98 & 3,75 & 0,97 \\
\hline \multicolumn{5}{|l|}{ Sport Biodynamics Knowledge } \\
\hline Physical qualities of athletes & 3.38 & 0,78 & 4,26 & 0,80 \\
\hline Motor development & 3,56 & 0,81 & 4,36 & 0,76 \\
\hline Biomechanics & 3,31 & 0,96 & 4,27 & 0,85 \\
\hline Physical exercise effects & 3,58 & 0,79 & 4,29 & 0,77 \\
\hline Exercise physiology & 3,07 & 1,03 & 4,10 & 0,99 \\
\hline Recovery after physical exertion & 3,50 & 1,01 & 4,20 & 0,80 \\
\hline Sports nutrition & 2,97 & 0,99 & 3,93 & 0,84 \\
\hline TOTAL & 3,34 & 0,91 & 4,20 & 0,83 \\
\hline \multicolumn{5}{|l|}{ Sport Psycho-socio-cultural Knowledge } \\
\hline Understanding and interpreting public behavior & 3.59 & 0,83 & 3,80 & 1,01 \\
\hline $\begin{array}{l}\text { Understanding and interpreting the } \\
\text { sportsmanship }\end{array}$ & 3,48 & 0,84 & 3,77 & 0,88 \\
\hline Understanding the role of sport in society today & 3,71 & 0,84 & 3,77 & 0,88 \\
\hline Strategies for the development of values & 3,65 & 0,91 & 4,34 & 0,73 \\
\hline Sport psychology & 3,31 & 0,85 & 3,91 & 0,96 \\
\hline TOTAL & 3.55 & 0,86 & 3.95 & 0,90 \\
\hline \multicolumn{5}{|l|}{ Sport Coaching Methodology } \\
\hline Technical and tactical aspects of the sport & 3.78 & 0,84 & 4,31 & 0,90 \\
\hline Theory and methodology of sports coaching & 3,46 & 0,84 & 4,20 & 0,83 \\
\hline Sport inicialization & 3,74 & 1,08 & 4,23 & 0,81 \\
\hline Evaluation techniques in sports & 3,51 & 0,86 & 4,10 & 0,83 \\
\hline Programming, planning and structuring coaching & 3,28 & 0,80 & 4,29 & 0,89 \\
\hline $\begin{array}{l}\text { Pedagogical principles in delivering coaching } \\
\text { sessions }\end{array}$ & 3,61 & 0,90 & 4,35 & 0,76 \\
\hline $\begin{array}{l}\text { Technical and tactical content of the mode in } \\
\text { which it operates }\end{array}$ & 3,97 & 0,86 & 4,55 & 0,76 \\
\hline TOTAL & 3,62 & 0,88 & 4,29 & 0,83 \\
\hline
\end{tabular}

Table 1-Descriptive statistics: self-perceived Professional Knowledge of Brazilian tennis coaches

Regarding the importance attached to Professional Knowledge, it was found that the related to the Theory and Methodology of training, and the Biodynamic were the most valued areas. These categories showed the highest levels of importance to all content, especially: those related to specific technicaltactical aspects; to knowledge about human development; those required to perform duties in training; and those about the effects of the activities and/or exercise. The Sports Management and Legislation category received the lowest level of importance, noting that the contents related to basic legislation were considered less important by the coaches.

Similarly to the results found in this study, the work by Egerland, Nascimento and Both (2009a, 2009b), and Egerland et al. (2013), with coaches operating in the sporting context of performance and different sports modalities (individual and collective), show that the knowledge related to Methodology of Sports Training and Biodynamic, are considered the most important. In these categories, the content related to technicaltactical aspects, specific of the sport, and athletic motor skills were those that received higher figures of importance. As was observed in this study, the Sports Management and Legislation category, received the lowest value (Egerland et al., 2013). The 
authors reported that academic training has shown to influence the importance attributed to Professional Knowledge, verifying that the postgraduate coaches gave more important to this knowledge when compared to graduate coaches (Egerland, Nascimento, Both, 2009b).

Specifically with tennis coaches, Fuentes and Villar (2004) describe the main Professional Knowledge needed for professional practice by referring to the basic teaching methodologies and the knowledge derived from sports sciences (physiology, biomechanics, psychology, motor learning, sports medicine and nutrition).

\section{CONCLUSION}

Regarding the perception of the domain Professional Knowledge, it is observed that the coaches presented lower values than those allocated to the importance, in all analyzed categories. The largest domain of knowledge referred to the related to Theory and Training Methodology, the Psychosocio-cultural aspects, and Biodynamics of Sport, meeting less significant values for Management and Sports Law knowledge. As observed in other studies, it was found that the more specific knowledge of the sport, related to Theory and Methodology of Training, and Biodynamic were the most valued by tennis coaches.

Even participating frequently in the context of non-formal learning and mediated situations, it was observed that Brazilian coaches reported lower dominance on the field of Professional Knowledge, when compared to the importance attached by them. Thus, it reinforces the need for training programs offering opportunities through different situations and learning contexts, so that this knowledge can be better developed.

The studies that deal with other skills, such as Interpersonal and Intrapersonal, appear as an important topic in the research agenda for the professional development of coaches. Understanding the knowledge necessary for professional practice in a contextualized way, and how they have been covered in the training programs, can contribute to the rapprochement between the activities offered in these programs and the interests and needs of coaches, making the learning process more significant .

Note: The authors thank the coaches who participated in the study and the support offered by Paraná Tennis Federation.

\section{REFERENCES}

Cortela, C. C., Aburachid, L. M., Souza, S. P., Cortela, D. N. R. \& Fuentes, J. P. G. (2013). A formação inicial e continuada dos treinadores paranaenses de Tênis. Conexões, Campinas, 11(2), 6084.https://doi.org/10.20396/conex.v11i2.8637617

Côté, J. \& Gilbert, W. (2009). An integrative definition of coaching effectiveness and expertise. International Journal of Sports Science and Coaching, 4(3), 307323.https://doi.org/10.1260/1747954097896238 92

Egerland, E. M., Salles, W. D. N., Barroso, M. L. C., Baldi, M. F. \& Nascimento, J. V. (2013). Potencialidades e necessidades profissionais na formação de treinadores desportivos. R. bras. Ci. e Mov, 21(2), 3138.https://doi.org/10.18511/0103-

1716/rbcm.v21n2p31-38
Egerland, E. M. (2009). Competências profissionais de treinadores esportivos. 86 p. Dissertação (Mestrado em Educação Física) - Programa de Pós-Graduação em Educação Física, Universidade Federal de Santa Catarina, Florianópolis, Brasil.

Egerland, E. M., Nascimento, J. V. \& Both, J. (2009a). Nível de associação entre a importância atribuída e a competência percebida de treinadores esportivos. Revista Pensar a Prática, 12(3), 113.https://doi.org/10.5216/rpp.v12i3.7621

Egerland, E. M., Nascimento, J. V. \& Both, J. (2009b). As competências profissionais de treinadores esportivos catarinenses. Motriz, v. 15, n. 4, p. 890899.

Fuentes, J. P. G. \& Villar, F. A. (2004). El entrenador de tenis de alto rendimento - un estudio sobre su formación inicial y permanente. Badajoz: APROSUBA -3.

Gilbert, W. \& Trudel, P. (2012). The role of deliberate practice in becoming an expert coach: Part 1- Defining coaching expertise. Olympic Coach Magazine, 23(3), 19-27.

Gilbert, W. \& Côté, J. (2013). Defining coaching effectiveness: a focus on coaches' knowledge. In: P. Potrac, W. Gilbert, \& J. Denison (Eds.). Routledge handbook of sports coaching (pp. 147-159). Abingdon: Routledge,International Council For Coaching Excellence - ICCE. (2012). International Sport Coaching Framework. 1.1a ed. Illinois. Human Kinetics Pub. Champaign.

Resende, R., Mesquita, I. \& Romero, J. F. (2007). Caracterização e representação dos treinadores acerca da formação de treinadores de voleibol em Portugal. EFdeportes. Disponível <http://www.efdeportes.com/efd112/formacaode-treinadores- de-voleibol-em-portugal.htm>. Acesso em: 22 abr. 2012.

RECOMMENDED ITF TENNIS ACADEMY CONTENT (CLICK BELOW)

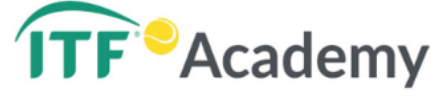

Copyright (c) Caio Cortela, Michel Milistetd, Larissa Galatti, Miguel Crespo and Carlos Balbinotti 2016

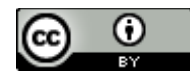

This text is under a Creative Commons BY 4.0 license

You are free to Share - copy and redistribute the material in any medium or format - and Adapt the content - remix, transform, and build upon the material for any purpose, even commercially under the following terms:

Attribution: You must give appropriate credit, provide a link to the license, and indicate if changes were made. You may do so in any reasonable manner, but not in any way that suggests the licensor endorses you or your use.

CC BY 4.0 license terms summary $\quad$ CC BY 4.0 license terms 